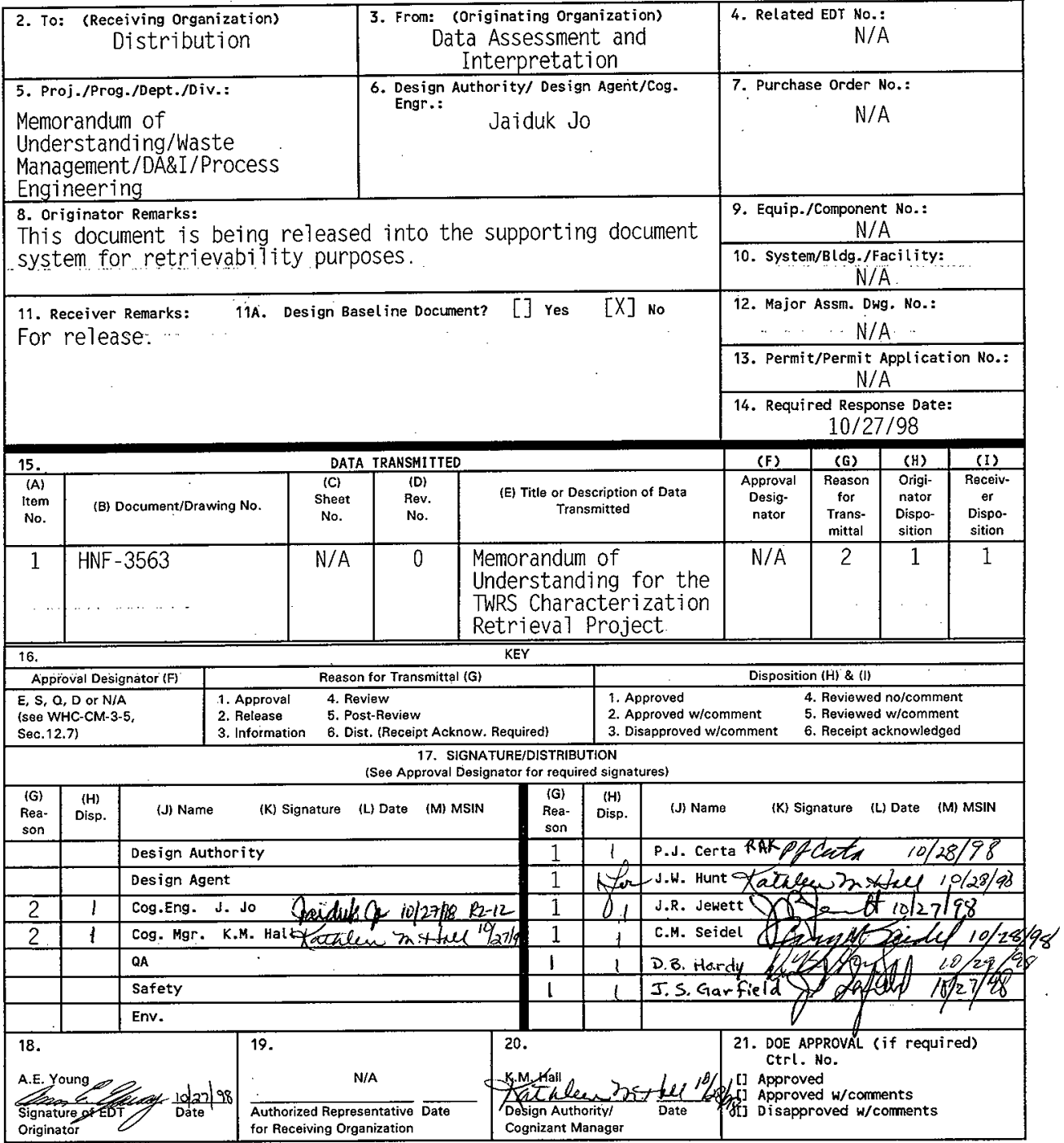




\section{Memorandum of Understanding for the TWRS Characterization Retrieval Project}

Jaiduk Jo

Lockheed Martin Hanford, Corp., Richland, WA 99352

U.S. Department of Energy Contract DE-AC06-96RL13200

EDT/ECN: EDT-622487 UC: 2070

Org Code: 74820 Charge Code: CACN 102209/COA EI00

BQR Code: EW 3120074 Total Pages: 5

Key Words: Memorandum of Understanding. MOU, TWRS. Characterization Retrieval Project, Characterization, Retrieval

Abstract: N/A

TRADEMARK DISCLAIMER. Reference herein to any specific commercial product, process, or service by trade name, trademark, manufacturer, or otherwise, does not necessarily constitute or imply its endorsement, recommendation, or favoring by the United States Government or any agency thereof or its contractors or subcontractors.

Printed in the United States of America. To obtain copies of this document, contact: Document Control Services, P.0. Box 950, Mailstop H6-08, Richtand WA 99352, Phone (509) 372-2420; Fax (509) 376-4989.
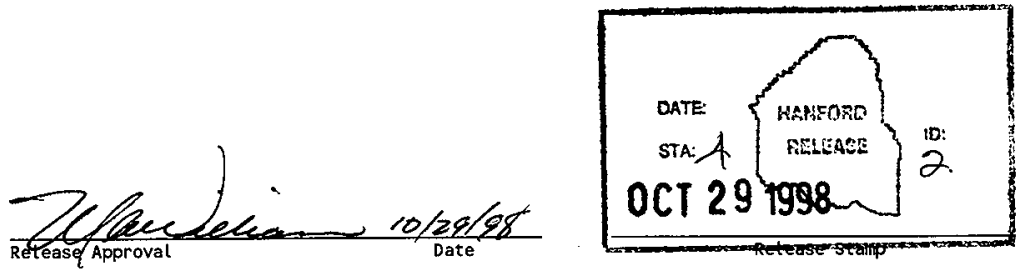

\section{Approved for Public Release}




\section{Memorandum of Understanding for the TWRS Characterization Retrieval Project}

J. Jo

Lockheed Martin Hanford Corporation

L. Amato

Los Alamos Technical Associates

Date Published

October 1998

Prepared for the U.S. Department of Energy Office of Environmental Restoration and Waste Management 
HNF-3563. Rev. 0

\subsection{INTRODUCTION}

During fiscal year 1999, various programs and projects will require analyses from the 222-S Laboratory. In order to prioritize and successfully meet the analytical demands of all the customers, multiple organizations across the Tank Waste Remediation System (TWRS) must work together. One of the projects that will require analyses from the 222-S Laboratory is the retrieval project. Successful completion of retrieval project objectives requires cooperation among four TWRS organizations. The requirements and expectations regarding retrieval project analytical work were examined in order to define roles and responsibilities for each of these TWRS organizations. This memorandum of understanding (MOU) documents the results of this review and establishes the roles and responsibilities.

This MOU is subdivided into three sections, the first of which is this introduction. Section 2 provides a summary of the overall roles and responsibilities with respect to retrieval project analytical work for the four TWRS organizations involved. The final section describes the individual interfaces involved in performing retrieval project analytical work, and discusses the roles and responsibilities with respect to each individual interface.

\subsection{SUMMARY OF ROLES AND RESPONSIBILITIES}

This section summarizes the generic roles and responsibilities of each TWRS organization with respect to analytical work required by the retrieval project. The four TWRS organizations that interface on this issue are Retrieval Engineering (RE), Process Engineering (PE), Process Chemistry (PC), and the 222-S Laboratory.

\subsection{Retrieval Engineering}

Any work for the retrieval project is initiated by RE. RE provides justifications and objectives for the analytical work, and provides technical input into planning the analytical work.

\subsection{Process Engineering}

The TWRS PE group is responsible for providing direction to the 222-S Laboratory and PC organizations. Direction is provided via Tank Sampling and Analysis Plans (TSAPs) and letters of instruction (LOIs). The TSAP is the primary documentation for initiating sampling activities, while both TSAPs and LOIs are used to start and direct analytical services. PE and RE share responsibility for developing data quality objectives (DQOs). 
HNF-3563. Rev. 0

\subsection{Process Chemistry}

The PC organization prepares and executes process test plans. This group documents the results of the process tests using reports.

\subsection{2-S Laboratory}

The 222-S Laboratory performs the tank waste analyses in accordance with the TSAPs and LOIs, and sends the analytical results back to the customers in the format requested. The 222-S is responsible for entering analytical data into the tank characterization database (TCD) for distribution and archival.

\subsection{DISCUSSION OF INTERFACES}

This section describes the individual interfaces associated with retrieval project analytical work and identifies the specific roles and responsibilities of each TWRS organization with regard to the interfaces. The flow of this discussion follows the flowchart presented in Figure 1.

RE initiates any work for the retrieval project using a direction letter. This letter provides a discussion of the outstanding issue(s) and the proposed method of resolution. This letter is sent to $\mathrm{PE}$, who in conjunction with RE writes a DQO and any tank-specific DQO addendums to address the data needs for resolving the particular issue. Using technical input from PE and $\mathrm{RE}, \mathrm{PC}$ prepares a test plan for the process tests.

If samples from the affected tanks are available and new sampling is not necessary; PE prepares an LOI for the 222-S Laboratory outlining the analytical plan for the samples. Should new sampling be required to meet the process test plan, PE produces a TSAP. The TSAP directs the sampling and analysis of the samples, and incorporates the requirements of the applicable DQOs, DQO addendums, and process test plan. Using either the LOI or the TSAP, the 222-S Laboratory prepares to receive the samples and schedules the analyses.

At the 222-S Laboratory, the samples are either received from the sampling crew or retrieved from archive. The 222-S Laboratory sends the raw undisturbed samples to PC, who performs the process tests. Depending on the process test plan, certain chemical analyses may be required. Therefore, during or after completing the process tests, PC may ship the samples back to the 222-S Laboratory for chemical analysis. The 222-S Laboratory forwards the results from the chemical analyses to PE, PC, and RE. PC produces the written data report, while 222-S Laboratory enters the analytical data into the tank characterization database. 
HNF-3563. Rev, 0

Figure 1. Retrieval Project Analytical Work Flowchart.

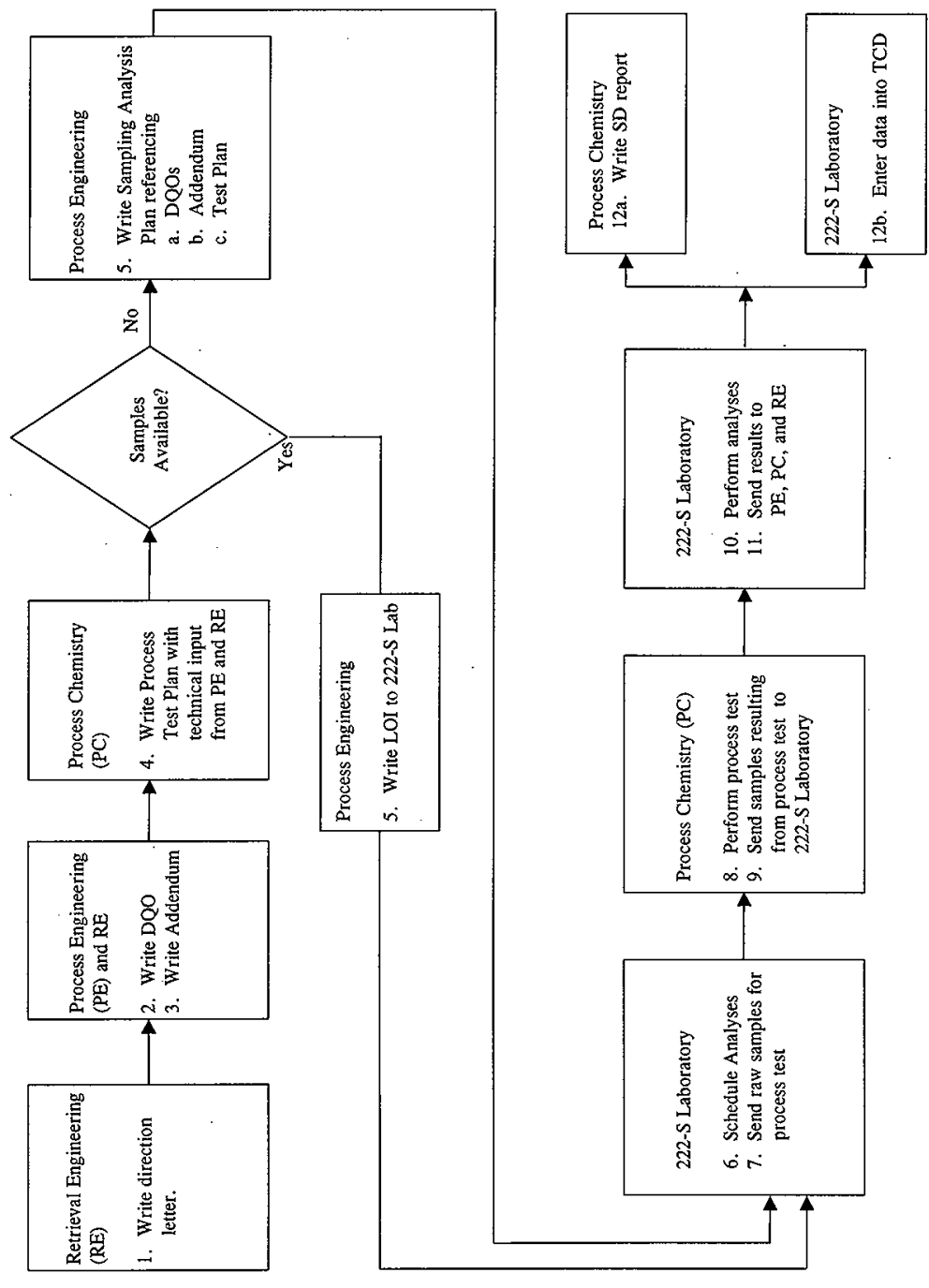


DISTRIBUTION SHEET

\begin{tabular}{|c|c|c|c|c|c|}
\hline \multirow[b]{2}{*}{ Distribution } & \multirow{2}{*}{\multicolumn{3}{|c|}{$\begin{array}{c}\text { Data Assessment a } \\
\text { Interpretation }\end{array}$}} & \multicolumn{2}{|l|}{ Page 1 of 1} \\
\hline & & & & \multicolumn{2}{|c|}{$10 / 27 / 98$} \\
\hline \multicolumn{4}{|l|}{ Project Title/Work Order } & \multicolumn{2}{|c|}{ EDT No. $\quad$ EDT-622487 } \\
\hline \multicolumn{4}{|c|}{$\begin{array}{l}\text { HNF-3563, Rev. 0, "Memorandum of Understanding for the TWRS } \\
\text { Characterization Retrieval Project" }\end{array}$} & \multicolumn{2}{|l|}{ ECN No. N/A } \\
\hline Name & MSIN & $\begin{array}{c}\text { Text } \\
\text { With } \\
\text { All } \\
\text { Attach. }\end{array}$ & Text Only & $\begin{array}{l}\text { Attach./ } \\
\text { Appendix } \\
\text { Only }\end{array}$ & $\begin{array}{l}\text { EDT/ECN } \\
\text { OnTy }\end{array}$ \\
\hline
\end{tabular}

U. S. Department of Enercy -

Richland Field Office

DOE/RL Reading Room

H2-53 X

Lockheed Martin Hanford Corp.

J. Jo

R. R. Thompson

T.C.S.R.C.

Lockheed Martin Services, Inc.

Central Files

Numatec Hanford Corporation

P. J. Certa

J. R. Jewett

Waste Manaqement Federal Services of Hanford, Inc.

C. M. Seidel

S3-30
R2-12

R2-12

R1-10

B1-07

X

R3-73

T6-07

$x$

X

$x$ 